\title{
STOPY HISTÓRIE 20. STOROČIA V REPETITÍVNYCH BÁSNICKÝCH TEXTOCH
}

\author{
JANA JUHÁSOVÁ
}

JUHÁSOVÁ, Jana: Traces of History of 20th Century in Repetitive Poetic Texts, 2019, Vol. 1, Issue 1, pp. 44 - 50. DOI: 10.17846/CEV.2019.01.1.44-50.

ABSTRACT: The paper "Traces of History of 20th Century in Repetitive Poetic Texts" discusses the socalled social litanies, the combination of the litanic repetitive form and of the historical-political theme, with a particular focus on the significant "eights" - the pivotal moments in the common Czech and Slovak history of the 20th century $(1938,1948,1968)$. The conclusion offers broader glimpse into the committed works of the contemporary Slovak poets.

KEYWORDS: Litanic Repetitive Form. Historical and Social Themes. Significant "Eights" of the 20th Century.

I ked’ relácia historickej témy a repetitívnej žánrovej formy, ktorej prototypom sú litánie, nie je v umení rozšírená, nemožno hovorit ani o jej marginálnosti. Vo francúzskej lyrike sú už od 12. storočia známe i tzv. politické či spoločenské litánie, ktoré toto spojenie legitimizujú (Sadowski 2016, 326). V polskej literatúre preslávili žáner napríklad Pútnické litánie (Litania pielgrzymska) Adama Mickiewicza z obdobia národného obrodenia.

Pri písaní monografie Litanická forma od avantgardy po súčasnost' (2018) som tiež našla niekolko repetitívnych textov so spoločenskou témou. Niektoré z nich priamo alebo implicitne reagujú aj na klúčové roky v spoločných dejinách českého a slovenského národa. Ukazuje sa, že historické traumy, ktorými roky 1938, 1948 a 1968 boli, sa v bohatej postojovej i emocionálnej škále demonštrovali aj na tomto úzko vymedzenom žánrovom poli.

\section{10. 1938 / ŽILINSKÁ DOHODA. AUTONÓMIA SLOVENSKA}

Litanická forma, napriek jej náboženskému pôvodu, bola v modernej lyrike 20. storočia oživená najmä vd’aka avantgardám - na Slovensku ich reprezentovali predovšetkým surrealisti (od februára 1939 premenovaní na nadrealistov). Pre básnických rebelov sa stali prítažlivé viaceré poetické tendencie litánií: rozbitie syntaxe, osamostatnenie pomenovania (obrazu) v rámci verša, nominálny princíp, uplatnenie anafory či tendovanie $\mathrm{k}$ volnému nestopovému veršu. Žáner aktualizovali podla vlastných preferencií: rezignovali na prosebnú čast’ verša, sakrálny princíp nahradili eroticko-tanatologickým, vzývanie alternovali opisom, odstránili alebo oslabili rámcovanie a podobne (Juhásová 2018,46). Spirituálni básnici z okruhu katolíckej moderny si osvojili novoobjavenú žánrovú formu v závislosti od sympatií alebo rezervovaného postoja k avantgarde. Pestovali ju tí, ktorým boli poetisticko-surrealistické výboje blízke, vyhýbali sa jej tradicionalisti, ktorí nechceli upadnút do podozrenia $\mathrm{z}$ koketérie s módnymi vlnami.

Koncom tridsiatych rokov 20. storočia, ked” sa odohral prvý z kontroverzných „osmičkových“ mílnikov - vyhlásenie štátnej autonómie, na Slovensku rozvíjali litanickú formu nadrealisti, ich obdivovatelia a progresívni básnici katolíckej moderny; názor na jesenné udalosti roku 1938 ich však postojovo polarizoval. Spirituálni autori uvítali samostatnost’ aj z dôvodu katolíckych štruktúr na čele neskoršieho štátu (Jozef Tiso) a možnostou výraznejšie vstupovat do spoločenských diskusií; surrealisti, naopak, prijímali fakt s obavami, že deklarovanie proslovenských tendencií bude zamerané proti ich nadnárodnej orientácii. 
V litanicko-repetitívnych textoch $\mathrm{z}$ tohto obdobia nachádzame smerom ku kontroverznej udalosti niekol'ko básní z oboch skupinových táborov. Na strane básnikov-kňazov privítal autonómiu básňou 6. X. 1938 (Cestami vetrov, 1938) Svetloslav Veigl; ozvennost̉ udalosti nachádzame tiež v Olivovej skladbe Madone VI (Oblaky, 1939).Veiglov text je uvedený euforickým zvolaním: „Mám v hlave závrat / a slzy na očiach / a v srdci nedozierne štastie“, „Slováci, Slovenky oslavujú dožinky“. Prúd variovaných obrazov, inšpirovaný prosebným typom verša z Litánií $k$ svätým, je s intenciou ochrany mladého štátu adresovaný Panne Márii. Autor kumuluje selankovité rekvizity národa a v synekdochickom usúvztažnení mu privoláva požehnanie a ochranu: „chráň oči od vášní mstitelov pohanských / (...) / pre lásku srdca materského, / pre lúbeznost’ rúčok najmenších, / (...) / pre púčky bližiacej sa jari, / pre lastovičie švitorenie a hladné mlád’atá, / pre gajdy s fujarou / (...) / Sedmibolestná" (1938, 66 - 67).

Obavy avantgardných umelcov z autonómie a vojnového konfliktu možno z ich básní (z dôvodu silnej metaforizácie) odčítat menej markantne, nie však neidentifikovatel'ne.Umelci kumulujú deformované obrazy tela alebo ženských monštier ako synekdochy neistého sveta a individuálnych vnútorných napätí. Na násilné rozdelenie Československa reaguje i Vladimír Reisel v skladbe Neskutočné mesto (1943). Jej námetom je vynútený odchod básnika-študenta z Prahy po vyhlásení Mníchovského diktátu a trpký rozchod s intenzívne prežívanou láskou. Do popredia sa dostávajú vo vnútornej pamäti pretvorené spomienky a sny s autobiografickými črtami. Básnik usúvztažňuje intímny mikropriestor s toposom mesta, uplatňujúc surrealistický postup reifikácie ženy a antropomorfizácie priestoru. Mesto v slede paralelných obrazov nadobúda črty ženy-milenky. Základné naladenie je rozlúčkové a oproti Veiglovej básni ponúka kontrastné pocitové asociácie: „Zbohom Emília / Zbohom neskutočné mesto / Mesto lásky a zrady / Mesto rúk ktoré som miloval / Mesto očí najpokornejších oči vesmíru / Mesto odovzdaného tela / Mesto úst stvorených iba pre lásku / Mesto úst schopných hovorit najláskavejšie slová / Mesto básnikov a samovrahov / Zbohom Emília / Zbohom neskutočné mesto" $(1943,49)$.

\section{2. 1948 / FEBRUÁROVÝ PREVRAT. KONIEC DEMOKRACIE}

Na rozdiel od udalostí spred desiatich rokov znamenal februárový prevrat pre spirituálnu tvorbu na Slovensku tvrdú skúšku. Básnikom-kňazom bola celoplošne zakázaná umelecká činnost’ a ich tvorba (okrem tej, ktorá sa prispôsobila požiadavkám socialistického realizmu, alebo jej autori už skôr emigrovali) vstúpila do dlhotrvajúceho vnútorného exilu. Naopak, nadrealisti skupinovo prešli do prorežimového tábora, pričom prejavom ich radikálnej „konverzie“ malo byt i zrieknutie sa avantgardnej poetiky (vrátane litanickej formy), ku ktorej sa postupne vracali až v priaznivejších šest'desiatych rokoch, no už s malou presvedčivostou. Repetitívno-variačnou formou, prispôsobenou požiadavkám socialistického realizmu,však vyjadrovali nové dobové heslá a idey básnici druhej poprevratovej generácie (napr. Ján Kostra, Pavol Horov), ktorí si ju ako prejav moderných tendencií osvojili ešte koncom tridsiatych a začiatkom štyridsiatych rokov a následne ju prispôsobili novým ideovo-poetickým očakávaniam. K nim sa pridávali autori z mladšej generácie (Miloš Krno, Krista Bendová, Pavel Koyš, Milan Lajčiak). Rok 1948 vyvolal v oboch menovaných táboroch (proskribovaní básnici exilu - oficiálna produkcia) ostro polarizovaný pohlad.

Na obdobie tušiaceho a následne naplneného povojnového útlaku reagujú viaceré básne Janka Silana, jedného zo zakladatelov časopisu Verbum (1946 - 1948); jeho vydávanie bolo po dvoch rokoch násilne zastavené. Básnik sa stal jednou z najvýraznejších, politickou mocou skúšaných postáv vnútorného exilu. Téma oscilujúca okolo temného historického medzníka roku 1948 je litanicko-repetitívnou formou zachytená v básni Čas, ktorá vyšla v poslednej slobodnej Silanovej zbierke Piesne zo Ždiaru (1947), a v básni Ó, Ježiš, studňa spasenia /20. 5. 1951/ (V zakliatej krajine, 
verše z rokov 1949 - 1958), napísanej v prvých rokoch totality. Oba texty odkazujú na obdobie tušiaceho a následne naplneného komunistického útlaku.

V básni Čas hromadí autor sériu expresívnych obrazov, ktoré vyvolávajú dojem emocionálneho napätia. Básnik sa koncentruje na kontrast svetla a tmy, ktorý má uňho etické vyústenie. Symbolicky sa v texte pripravuje boj medzi dobrom, ktoré reprezentuje kňaz (lyrický subjekt; vo vertikálnej metafore sa rýmuje so slovom „jas“), a zlom, ktoré zastupujú tí, „pre ktorých všetci poblúdia“. Centrálna lexéma (čas) je v rade obrazov umiestňovaná na sémanticky nosné pozície - na začiatok verša ako anafora, čo je pre litánie typické, ale tiež na záver, kde vytvára priestor pre vertikálnu metaforu - čas: d’as, plaz, z más, (Antikristov) hodokvas. Boj so zlom sa demonštruje ako zápas dvoch optík - nedeformovanej (kňazovej), ktorá vidí tmu tam, kde je zlo, a teda i v čase, ktorý nastáva: „ty ošemetný zradný čas, / čas bez ozdoby, / čas chmúrny ako d’as, I čas bez podoby, / v ktorom je človek horší, než je plaz, I v ktorom si robí / z más, / hla, Antikrist sám cesto na svoj hodokvas“; a ludí poblúdeného sveta. Pre tých je svetlo nepríjemné, ba hrozivé: „a ja som pre svet obluda, / ja zavadziam tu, to je žas, / nuž nech ma dajú do kúta, / ale ja prskat budem svetlo zas, / ale ja hrozný osvietim si vás, / vy obielené hroby“ $(1996,208)$. Dikcia s expresívnym nábojom je blízka žalmickej emfáze.

V prorežimových básňach, naopak, bol „Vítazný február“ vnímaný ako koniec „temného“ času a začiatok „svetlej“ pofebruárovej budúcnosti. Je príznačné, že aj tieto texty pracovali vo zvýšenej miere s náboženskými inšpiráciami a formami, hoci významovo ich hodnotovost̉ popierali. Filiáciu socialistického umenia k náboženským formám a symbolom postrehol tiež René Bílik: „Ideologická moc sa (...) śtylizovala do podoby, nedotknutelného božstva’ a tak sa aj prezentovala. Súčasne vystupovala ako, všemohúca', ako ,stvoritel'ka nového sveta' a spasitel'ka civilizácie‘ (...). Usilovala sa popri tom deštruovat práve ony tradičné civilizačné (krestanské) hodnoty, poukazujúc na ich reakčnost', a ponúknut' sama seba ako novú alternatívu“ (2008, 85). Repetitívna forma, tendujúca k óde, agitke a polemike, bola v duchu nového poetického kánonu (socrealizmu) naplňaná zjednodušenými tvarovými riešeniami, ktorých súčastou boli priame pomenovania, pátos, alegorický princíp a tendenčný, idealizovaný obsah: oslava práce, bojová tradícia, prosovietska orientácia, revolučná vyspelost’ či kolektívna identita. Častou podobou litanickej formy bolo v ideologicky podmienenej prevádzke aj centralizovanie aspektov s bipolárnym hodnotovým nábojom (dobrí my - zlí oni; chaotické vtedy - usporiadané a zmysluplné teraz). Tieto znaky nájdeme napríklad v Horovovej ódickej básni Zdravica, venovanej komunistickému funkcionárovi Viliamovi Širokému, reprezentantovi prosovietskeho teroru a čistiek vo vnútri strany, ktorá vyšla v kolektívnom zborníku Zdravica slovenských básnikov Viliamovi Širokému (1952) pri príležitosti jeho pätdesiatych narodenín.

\section{AUGUST 1968 / NÁSTUP "MÄKKEJ TOTALITY"}

Tibor Žilka spája „mäkkú totalitu“, odvíjajúcu sa od augustových udalostí ‘68, s revitalizáciou vedúcej úlohy KSČ v čase normalizácie. Na jednej strane je charakteristická návratom k metódam z obdobia pätdesiatych rokov, no v menej drastickej forme, čo umožnilo rozvinút aj alternatívny spôsob života a tvorby, vrátane kritiky súdobej spoločnosti a svedectva „o koloniálnom stave duchovného života“ (Žilka 2015, 34 - 36). V poézii sedemdesiatych rokov sa na jednej strane opätovne stretávame s postupmi nadväzujúcimi na poetiku schematizmu, na druhej však s prirodzeným gestom odporu, reagujúcim na udalosti 21. augusta traumatizujúco.

Diferencovanie medzi programovým „my - oni“ ako klúčový princíp ideologicky podmieneného umenia využil v skladbe Slovo (1976), venovanej Komunistickej strane, aj Miroslav Válek, $\mathrm{v}$ čase tvorby textu už etablovaný minister kultúry. Válek v porovnaní s Horovom nevytvára antagonistickú, ale komplementárnu dvojicu, ktorej protagonistami sú „dokonalá“ proletárska vlast” 
(1976, 37) a „nedokonalý“, ale od nej závislý lyrický subjekt. Povahu enumeratívneho apostrofovania majú pasáže štvrtej časti, pričom striedajúce sa dvojobrazy s opakujúcou sa sponou „To ja“ - „To ty“ sú rozpísané a vyčlenené v samostatných krátkych strofách: „To ja tam svetielkujem v prítmí / podkrovného bytu. / To ja ti vzlykám rytmy brutálneho beatu. // To ty si slovo láska / napísané na tabuli sveta / bielou kriedou. // To ja som plný narkotík / a jedov. / Spím iba s najhoršími, / to sú: hnev a nenávist. / To ty po krutej smrti zimy / vstaneš svieža, zelená. / To ty si úsvit, zažíhanie hviezd. // To ja som suchýlist / Pavla Verlaina, / hnaný víchrom / pozdlž tvojich ciest. / To ty si dobrá zvest" (1976, 27 - 28). Napriek Válkovej kreatívnej obraznosti a postupom pripomína text v celkovom vyznení verejné sebakritiky, vynucované od umelcov v čase kultu osobnosti.

Z opačného hodnotiaceho pohladu vnímajú nástup normalizácie skladby Jána Buzzásyho či Jozefa Mokoša; možno ich vnímat ako odvážny prejav dobového nesúhlasu. Buzássymu, vyradenému po zániku Mladej tvorby z tvorivej práce, sa v skladbe Pláň (1970) podarilo kódovanou obraznostou vyjadrit bolest’ z tlaku nastupujúcej „konsolidačnej“ odysey. Podobu litanickej formy má štvrtá, záverečná čast’ skladby s názvom Ty, ktorý: „Ty, ktorý stúpaš do tiesňav, / ty luk, napinaný božou tetivou, ty na prasknutie, / vystrelujúci šípy, ktorým duša obhrýzla konce, / ty boží koncept, obet' na nečisto, / (...) / ty, človek, ktorý videl svet: pod vlastný obraz, ty spitý, / (...) / ktorý kráčaš do toho ohňa a, bojac sa krásy, / cúvaš k estetike, aby si nakoniec získal len sumu neistôt, / ty taký cudzí, prašivý prachom svojej zeme, / (...) // Cudzinec, stavajúci svoj domov na vlastných rukách, / (...) / človek prachu, do ktorého boh pluje, a vidiš: / pluje krv" (jún - august 1970) (2012, 56 - 57). Na rozdiel od schematických textov je Buzássyho skladba budovaná princípom významovo vrstvenej obraznosti. Téma je nasvecovaná $\mathrm{z}$ rôznych, aj paradoxných uhlov vnímania (bezútešnost̉ - hladanie záchytného bodu). Lyrický subjekt precituje svoje postavenie „človeka obsadeného“ (Gavura 2012, 69) v ambivalentnom rozpoložení - ako opustenost', skúšku, aj posilu zo strany Boha. Kráčanie do tiesňav je obrazom oklieštených vonkajších možností (neslobody, duchovnej prázdnoty), prinášajúcich pocit stratenej životnej šance, ale aj sebavýzvou k hladaniu krásy ako možného dôvodu, prečo vôbec žit. Na spôsob monumentálnej modernej poézie (W. Whitman, T. S. Eliot, A. Ginsberg, E. Pound) pracuje básnik so širokodychým veršom nerovnakej dĺžky, harmonizujúcim s rytmom ludského dychu, a s vozvýšeným tónom. Je známe, že necenzúrovanú verziu skladby Pláň, inšpirovanú najmä Eliotovou Pustatinou, vydal Buzássy až v roku 2012. Cenzúrou oklieštená skladba s názvom Plán̆, hory vyšla v roku 1982.

Jesenné litánie (1969) Jozefa Mokoša boli hned’ po publikovaní stiahnuté z distribúcie a básnik sa kvôli otvorenej vzbure voči násilnej intervencii dostal na listinu zakázaných autorov (skladbu tiež odvysielal Slovenský rozhlas 16. januára 1970 na prvé výročie upálenia Jána Palacha). Sakrálno-prírodné motívy pašiovej tonality sú, podobne ako naturomorfný obraz Buzássyho pláne-pustatiny, metaforami bolestnej, nepriaznivej doby. Prvá čast̉ skladby napĺña žánrovú podstatu názvu - po viacnásobných invokáciách s hymnicko-elegickým nástupom, vyčlenených v samostatných veršoch („Ó čas odtláčania Ježišovej tváre do listu viniča / Ó vietor pištiaci pri vyorávaní myších hniezd / Ó úzkost kurzívových mušiek v blikajúcom ohníku medu / Ó oči srny poznávajúce svoj žltý vlas v hrebeni parohov na štíte horárne / Ó smutné šerenie bez ostrých plamienkov bocianích zobákov“) a prosebnou sponou „oroduj za nás“ nasleduje záverečná modlitba: „Modlime sa, / aby / len / plodová voda luny / mužom / mozgy zmenšovala / k obrazu tých / v orechovej lebke / a aby sme $v$ tme daždov / uvideli / náhle zrážanie bielych krviniek / na našej igelitovej koži / i / vystreli pred seba ruku / po jazvách, aspoň po jazvách, / aby sme sa ešte poznali“ (1969, 3 - 4). Mokoš analogicky k textom režimových básnikov využíva kontrastovanie časových rovín, tu však v obrátenej významovej tonalite - predchádzajúce teplé leto strieda nastávajúca sychravá jeseň. Tenzívne prírodné obrazy s dôrazom na senzuálnost' sú zjednotené spiritualizačnou metaforou zmučenej Ježišovej tváre otlačenej v scenérii krajiny. Modlitba je prosbou za schopnost’ dôstojného prežitia, hoci s vedomím strádania. Andrea Bokníková $(2012,58)$, reflektujúca skladbu v celostnej kompozícii 
Štyroch nočných období (2002), do ktorej autor dodatočne skomponoval na spôsob Vivaldiho série huslových koncertov súhrn svojej tvorby, spája Jesenné litánie, jej tretiu čast', s pocitovou jeseňou.

\section{PONOVEMBROVÉ REMINISCENCIE, KRITIKY A ODHODLANIA}

Publikačný zákaz, dokonca odňatie slobody, postihli ešte v čase tvrdej totalitnej moci aj Rudolfa Dobiáša. Osem rokov (1953 - 1960) strávil ako politický väzeň v uránových baniach v Jáchymove. Jeho umeleckou reakciou sú Litánie $k$ slobode, ktoré publikoval až v čase politickej slobody, v roku 2009. Skladba má na spôsob krížovej cesty štrnásť častí a záverečný text oslavného ladenia „Ave, milostiplná sloboda, / ty Bohom požehnaný dar, / si naše vzkriesenie i zmar, / vždy d’aleká, navždy

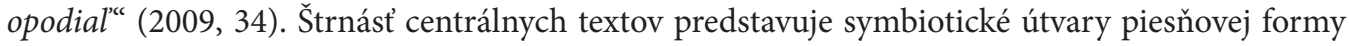
a shakespearovského sonetu. Každá báseň má štrnást' veršov členených na tri štvorveršia a záverečné dvojveršie, pričom obkročné rýmy v štvorveršiach sú volne alternované striedavým rýmovaním. Básne sú radené na spôsob sonetového venca - posledný verš predchádzajúceho textu tvorí incipit nasledujúceho, hoci záverečná báseň nemá povahu královského sonetu. Textové postupy zjednocuje snaha budovat útvar vysokej lyriky, pomník dlho vydobýjanej slobode. Dobiáš rozpisuje charakterizačné obrazy od rozpätia jedného verša „ty čo si vždycky v práve, / ty levie mlád’a hravé" (ibid., 16) až k celej strofe „ty, čo si zišla z hájov / do mojej plytčiny / pre slávu prvých májov / a iné príčiny“ (ibid., 6). Ako častý výstavbový postup využíva oxymoron a zvukové zvýznamňovanie, typické pre biblické žalmy: „bremeno milované, „ty brána väzenia, / ty večne väznená“ (ibid., 6), „Ty nevernica verná“ (ibid., 4), „očistec bez spasenia“ (ibid., 16), vrátane expresívnej dikcie: „ty hanba justície, / vrah dosial’ bez mena“ (ibid., 8), „ty, čo si potravou / pre šelmy v ludskom dave“ (ibid., 18). Sloboda nadobúda podobu prekliatia a spásy zároveň.

Ako gesto ponovembrovej úlavy čítame aj báseň Štefana Moravčíka, ktorý od počiatku kládol sofistikovane odpor neslobode. Za neprispôsobivosṫ mu bol nariadený niekolkoročný publikačný zákaz. V roku 1989 ako jeden z prvých privítal obdobie politickej slobody básňou Bojujúcej Bratislave, datovanej 27. novembra 1989 (Ludský sendvič, 1991). Súčastou básne je priznaný náboženský výraz i aktuálne ekologické znepokojenie: „Bud’ blahoslavená, Bratislava, / (...) / bez bývalých bohov, bez bilagu bludov, / bez bezohladných buldozérov, búračiek, / bez betónových bonboniér, I bez benzinových brudov... / (...) / Bud'blažená, Bratislava budúcnosti, / bez bičov božích, bez blenu bližnych / Bratislavčanov! Bud’ bezpečným bývaním, // (...) // Bud' blahoslavená, Bratislava, / bud' bezvadná, bud’božská!“(1991, 48 - 49).

V povojnovej a súčasnej tvorbe sa model spoločenských litánií uplatnil aj pri iných ako politických témach. Reflektujú sa nielen konkrétne historické mílniky, ale aj znepokojivý stav sveta. Už u proavantgardne orientovaných básnikov z generácie Mladej tvorby (Miroslav Válek, Mikuláš Kováč, Ivan Štrpka), neskôr u Daniela Heviera, Róberta Hakalu či u spirituálnych autorov Mariána Milčáka a Daniela Pastirčáka sa objavujú obavy z eticky nezvládaného technického pokroku a zo straty ludskosti. Ponovembrové dystopie sa viac sústredujú na degradujúce procesy v zmysle nahrádzania ludského (axiologického) prvku kyborgickým, komerčným alebo fobiotickým. Od prvej dekády 21. storočia sa objavujú najmä v tvorbe básnikov text generation (Peter Macsovszky, Michal Habaj, Peter Šulej), u anestetických autoriek (Mária Ferenčuhová, Katarína Kucbelová) a u básnikov pracujúcich s postupmi popkultúry (Viliam Klimáček, Mirka Ábelová). Autori budujú výpoved' na možnosti neprvoplánového, viacúrovňového čítania; prirad’ovanie paralelných jednotiek má procesuálny charakter, ktorý imituje odosobnené výrobné procesy, ale aj pohyb vedomia - jeho postupné prelad’ovanie do iného, často deštrukčného módu (napr. v básni Kataríny Kucbelovej Branné cvičenie, zb. Vie, čo urobí, 2013 alebo v texte Michala Habaja Výzva, zb. Caput Mortuum, 2015). Kucbelovej báseň Branné cvičenie je pohladom do vnútra patologického človeka neprirodzene sa brániaceho pred akoukolvek (národnostnou, rasovou, 
majetkovou, sociálnou, politickou...) odlišnostou: „brániš sa pred tým, kto má vä̌̌ší a lepšsi dom, pozerá iné televízne programy, má telesnú zvláštnost', je krajší, volí inú politickú stranu, platí dane, hovorí sa o ňom, že je prekliaty, je inteligentnejší, prišiel z ovel'a chudobnejšej krajiny, je vyšší, jeho otec bol vo väzení, nesútaží, je prekliaty, má lepšie vzdelanie, má duševnú chorobu, jedáva vela ovocia a zeleniny, má iný prízvuk, rozumie cudziemu jazyku, má viac peňazí, prišiel z iného mesta, má vela peňazí, má vela tajomstiev, dôsledne recykluje odpad, (...), nevieš či existuje" (2013, 20 - 21). Autorka uprednostňuje kontinuálny textový zápis imitujúci bujnejúcu fóbiu zapĺnajúcu vedomie obrazmi strachu. Rytmus založený na dlhom monotónnom opakovaní a návratnosti motívov imituje postupnú zmenu stavu vedomia odpojeného od bežného, každodenného ja, vedúceho až k zastieraniu identity a následne lahkej manipulovatel’nosti: „niekedy ho (iného človeka, pozn. J. J.) stačí zosmiešnit', niekedy zastrašit', niekedy urazit', (...), niekedy zbit', niekedy zabit', musís byt' na pozore, kto t’a ochráni, ked’ včas nezaútočíš? " $(2013,21)$.

\section{SUMMARY}

In art history, the social and political litanies have been present since the 12th century. After the revival of the litanic form by the avant-garde poetics, the frequency of the appearance of the genre in the Slovak modern poetry has increased. Using multiple parallelisms (thematic, syntactic, intonational) and an emphasis on characterisation, the authors accumulate positive or negative images with heightened emotional charge. The controversial years 1938, 1948 and 1968 usually bring about contrasting reactions; for surrealists, the poets of the Catholic modernism, it is the internal exile; for the state approved mainstream poets, such as the social realists, it is the straightforward modern discourse. The paper deals most particularly with the texts by S. Veigl, V. Reisel, J. Silan, M. Válek, J. Buzássy, J. Mokoš, R. Dobiáš, Š. Moravčík and K. Kucbelová. The author is also attempting to capture the developmental changes of the litanic form in its different poetic and historical renderings. She argues that some elements of social litanies can also be found in contemporary poetry, especially in the 2000s. Poets moderate the unwelcome pathos and explicit criticism applying the principles of grotesque, the rollage building of the text, and the cinematic, pop culture or cyberculture techniques.

Štúdia je výstupom projektu VEGA 1/0523/18 Lexikón slovenskej literatúry a kultúry 1989 - 2015 (autori, diela, procesy a intermediálne presahy).

\section{LITERATÚRA}

Bílik, René, 2008. Duch na retazi. Sondy do literárneho života na Slovensku v rokoch 1945 - 1989. Bratislava: Kalligram.

Bokníková, Andrea, 2012. Zo slovenskej poézie 60. rokov 20. storočia I. Bratislava: Univerzita Komenského.

Buzássy, Ján, 2012. Pláň. Košice: Európsky dom poézie.

Dobiáš, Rudolf, 2009. Litánie k slobode. Prešov: Vydavatelstvo Michala Vaška.

Gavura, Ján, 2012. Hlas človeka obsadeného. In: Buzássy, Ján: Pláň. Košice: Európsky dom poézie. Habaj, Michal, 2015. Caput Mortuum. Bratislava: Drewo a srd.

Horov, Pavol a kol., 1952. Zdravica slovenských básnikov Viliamovi Širokému. Bratislava: Slovenský spisovatel.'

Juhásová, Jana, 2018. Litanická forma od avantgardy po súčasnost'. Ružomberok: VERBUM.

Kucbelová, Katarína, 2013. Vie, čo urobí. Bratislava: Artforum.

Mokoš, Jozef, 1969. Jesenné litánie. Martin: Matica slovenská. 
Moravčík, Štefan, 1991. Ludský sendvič. Bratislava: Slovenský spisovatel'.

Oliva, Palo, 1939. Oblaky. Trnava: Urbánek a spol.

Reisel, Vladimír, 1943. Neskutočné mesto. Bratislava: Skarabeus.

Sadowski, Witold, 2016. Polish Litanic Verse until 1939. An Outside Perspective. In: Sadowski, Witold - Kowalska, Magdalena - Kubas, Magdalena Maria (eds.): Litanic Verse I. Origines, Iberia, Slavia et Europa Media. Frankfurt am Main: Peter Lang Edition.

Silan, Janko, 1996. Piesne zo Ždiaru. In: Pašteka, Július (ed.): Janko Silan: Súborné dielo zv. 2. Bratislava: LÚČ.

Silan, Janko, 1998. V zakliatej krajine (verše z rokov 1949 - 1958). In: Pašteka, Július (ed.): Janko Silan: Súborné dielo zv. 7. Bratislava: LÚČ.

Válek, Miroslav, 1976. Slovo. Bratislava: Smena.

Veigl, Svetloslav, 1938. Cestami vetrov. Bratislava: U nás.

Žilka, Tibor, 2015. Dobrodružstvo teórie tvorby. Nitra: Univerzita Konštantína Filozofa v Nitre Fakulta stredoeurópskych štúdií.

\section{KONTAKT}

Mgr. Jana Juhásová, PhD.

Katedra slovenského jazyka a literatúry

Filozofická fakulta KU v Ružomberku

Hrabovská cesta 1B

03401 Ružomberok

Slovenská republika

jana.juhasova@ku.sk 